\title{
Working capital financing and corporate profitability in the ASEAN region: The role of financial development
}

\author{
Rahmat Heru Setianto, Rani Septiani Sipayung, W.N.W. Azman-Saini
}

\begin{abstract}
A B S T R A C T
Objective: This article empirically investigates the role played by financial development in determining the relationship between working capital financing and firms' profitability.

Research Design \& Methods: Employing data of publicly listed manufacturing firms in five ASEAN countries - namely Indonesia, Malaysia, Philippines, Singapore, and Thailand - spanning 2009-2018, resulted in 6183 firm-years observations. This study conducts an analysis using the two-steps generalized method of moments (GMM) estimator.

Findings: The inverted $U$-shape effect of working capital financing on firm profitability is confirmed. Moreover, new evidence appeared that firms which operate in more financially developed regions have the opportunity to utilise a greater percentage of short-term debt without destroying their profitability.

Implications \& Recommendations: Corporate managers should avoid using excessive short-term debt to finance their working capital requirement as the risk of refinancing and interest outweigh its benefit. Secondly, given the significant role played by financial development, policy makers should give priority to financial reforms and development to ensure firms have access to finance and hence foster their growth for the benefit of the economy.

Contribution \& Value Added: This article contributes to the existing literature in two ways. Firstly, this is the first study to analyse the role of financial development on working capital financing and profitability relationship. Secondly, the study extends the insight of this research area onto a large emerging region that has never been studied before: the ASEAN region.

\section{Article type: research article}

Keywords: $\quad$ working capital financing; financial development; performance

JEL codes: $\quad$ G30, G32

Received: 1 January 2021 Revised: 7 September 2021 Accepted: 30 September 2021
\end{abstract}

\section{Suggested citation:}

Setianto, R.H., Sipayung, R.S., \& Azman-Saini, W.N.W. (2022). Working capital financing and corporate profitability in the ASEAN region: The role of financial development. Entrepreneurial Business and Economics Review, 10(1), 51-64. https://doi.org/10.15678/EBER.2022.100104

\section{INTRODUCTION}

Working capital management is essential to firms' decision-making. Working capital policies are necessary for the firm as they have direct effects on day-to-day activities, which in turn affect company performance. Corporate finance literature argues that managing working capital focuses on two aspects, namely investment and financing decisions. So far, there have been numerous empirical studies examining the effect of working capital investment on firm performance (e.g. Shin \& Soenen, 1998; Deloof, 2003; Kieschnick et al., 2013; Aktas et al., 2015; Baños-Caballero et al., 2014; Charitou et al., 2012; Setianto \& Pratiwi, 2019). However, studies on the financing of working capital are very limited; so far, three empirical studies have examined the impact of financing policy of working capital requirements on performance (Baños-Caballero et al., 2016; Altaf \& Ahmad, 2019; Pandan \& Nanda, 2018).

To finance their working capital, firms have two alternatives, namely internal financing sources using free cash flow or external funding sources using debt or equity. Theoretically, financial managers 
may adopt conservative or aggressive financing strategies, with each of these strategies having specific costs and benefits. Thus, managers must find an optimal combination between short-term and longterm sources when financing their working capital requirements and maximizing firm performance.

Few empirical studies identify the impact of working capital financing (WCF) on company performance. Baños-Caballero et al. (2016) are the first to examine the case of Spanish firms. They found that working capital financing strategies have an inverted U-shaped effect on performance. Studies conducted in India by Altaf and Ahmad (2019) and Pandan and Nanda (2018) have revealed a U-shaped relationship, which indicates that both conservative and aggressive financing strategy will have a positive effect on firm profitability. So far, there are only three studies that have examined the relationship of working capital financing and company performance, thus encouraging this study to expand research in this field to the context of manufacturing companies in the ASEAN region.

The main objective of this study is to examine the role of financial development on the relationship between working capital financing and profitability in ASEAN countries. This article attempts to contribute to this line of enquiry in several novel ways. Firstly, complementing the previous studies in working capital financing, we analyse the role played by financial development, a factor that has not been examined previously. Cross-country studies conducted by Rajan and Zingales (1995) and Booth et al. (2001) suggest that financial development is a primary factor that affect firms' financing decisions. It means that financial development could possibly become a factor that determines the relationship between working capital financing and firm performance. The level of financial development in which a company operates will determine the ease of access to external financing. Financial development will expand firms' financing sources, reduce financial constraints, and effectively decrease the cost of external financing. De Carvalho (2009) argues that bank and other financial institutions' credit is easier to access by the firms in countries with advanced degrees of financial development. Accordingly, we see a need to scrutinise whether financial development is a factor that can determine the working capital financing and performance relationships.

Secondly, ours is the first study to analyse working capital financing in the ASEAN context. The ASEAN region has the potential to be an interesting example because it consists of developing countries with unique characteristics and world attention. According to the World Bank, the ASEAN's contribution to the global economy reached $3.5 \%$ in 2018. The ASEAN region has a very large domestic market, reaching 642 million people, with a very large middle class, causing the economy in this region to grow rapidly by $5.9 \%$ each year, far higher than global economic growth, which typically reaches only $3.8 \%$. This wide-open business opportunity provides a strong incentive for companies in this region to grow more rapidly. Expansion becomes a choice that must be taken by the company, causing greater complexity in managing a business, including working capital. On the other hand, when compared to developed countries' financial markets, ASEAN countries' financial markets are relatively underdeveloped. As stated by Gertner et al. (1994) and Lee et al. (2012), companies in emerging markets may rely more on internal funds and banks as sources of financing because their stock markets are less developed. The banking sector is still the main form of financial intermediation and the major source of external capital for companies and parties who need capital to run their business (Mishkin, 2001). Some of the above characteristics may not occur in places where other previous studies were conducted. Therefore, this study is expected to fill research gaps and broaden understanding related to the working capital financing strategies in the setting of large emerging markets.

Thirdly, this study conducted an analysis by employing panel data procedure to account for the unobservable heterogeneity. Lastly, the generalized method of moments (GMM) technique was employed to overcome the potential problem of endogeneity.

In this study, a concave relationship is demonstrated between short-term debt financing of working capital requirement and performance. That is, the effect of working capital financing is positive at low portions of short-term debt and negative at greater levels of short-term debt. In addition, new evidence is found that the optimal level of short-term debt financing is changed not only due to the degree of financial constraints faced by each firm but also due to the degree of financial development 
of the country where the firm operates. Firms in the higher level of financial development region exhibit higher optimum levels of short-term debt financing. These results are robust by the introduction of various proxies of financial constraints and country level of financial development.

The rest of the article is organized as follows. The next section will review the relevant literature on the relation between working capital financing, firm performance, financial constraints, and financial development. Section 3 will demonstrate the data, variables, and empirical approach. Section 4 will present the estimation results, and the final section will offer concluding remarks.

\section{LITERATURE REVIEW AND HYPOTHESES DEVELOPMENT}

\section{Working capital financing and firm performance}

Traditional corporate finance literature suggests that strategies in financing current assets affect performance (Smith, 1980; Van Horne, 1969). However, few empirical studies examine the relationship. Theoretically, working capital requirement is the gap between current assets and accounts payables. If the current asset is greater than the account payables, financial manager has to seek the most suitable funding source to finance the working capital requirement. For that purpose, financial manager may choose between short-term and long-term sources of financing; the choice will determine whether the manager adopts a conservative or aggressive strategy in financing the working capital requirement. Both strategies have their own costs and benefits; it is contingent upon internal and external conditions of each company (Baños-Caballero et al., 2016). It is the challenge for managers to align the policies with company characteristics and hence will lift company performance.

Very limited empirical research provides evidence of the significant relationship between financing of working capital policies and financial performance. Baños-Caballero et al. (2016) first investigate the impact of working capital financing and profitability for the case of small and medium-sized enterprises (SME) in Spain. They found that the impact of working capital financing on performance was to follow the inverted U-shape. Another study by Pandan and Nanda (2018) suggests different patterns of working capital financing and profitability relationship across sectors in India. They found that aggressive strategy resulted in higher profitability for chemical, construction, and consumer good sectors, while a concave pattern was found for machinery, metal, and textile industries. The most recent study conducted by Altaf and Ahmad (2019) in India supports the concave relationship of financing in working capital and performance.

Since previous studies suggest the non-linear effect of working capital financing policies on performance, it implies that finance of working capital requirement with short-term debt will brings some benefits for the firm; however, it also carries substantial risk. Therefore, the effect may either be positive or negative.

The greater proportion of working capital requirement funded by short-term debt has several positive impacts on company performance. Jun and Jen (2003) argue that short-term debt has a lower default and inflation risk than long term debt, hence the lower nominal interest rates of short-term debt. Short-term debt is also easily adjusted based on the firm's financial condition. Short-term financing can reduce agency problems between shareholders and debtholders because there are other parties, namely creditors who also oversee the management (Baños-Caballero et al., 2016). Moreover, the existence of debt can also reduce the cost of equity agents. Short-term financing can solve the problem of underinvestment due to periodic credit renewals, so companies that need financing for investment can issue short-term debt to reduce underinvestment risk in the company (Ozkan, 2000).

Conversely, the excessive use of short-term debt is likely to impose an adverse effect on company performance. Firms will face higher refinancing and interest rate risks if the working capital requirement for financing uses a large percentage of short-term credit. As short-term credit has a short maturity period, companies may possibly find it difficult to refinance their short-term debt and may have to bear greater cost of funds when making new loans; hence using too much short-term loan to finance working capital requirement will harm company performance (Baños-Caballero et al., 2016).

Based on these arguments, the advantages and disadvantages of short-term debt that will be felt by firm depend on the proportions used. When the proportion of working capital backed by 
short-term debt is low, an addition in short-term debt will increase company performance because the benefits outweigh the costs. Conversely, when the percentage of short term-debt is high, an addition to short-term loan to finance working capital requirement may result in declining firm performance, since the costs incurred may exceed the benefits (Baños-Caballero et al., 2016). Thus, it is possible to have a reversed U-shape effect of working capital financing on company performance. Therefore, we posit the following hypothesis :

H1: The effect of short-term debt used to finance working capital requirement on profitability follows an inverted U-shape.

\section{Working capital financing and the effect of financial development}

Modigliani and Miller (1958) suggest that in a frictionless world, firms can easily access external financing without barriers, so internal capital is not the only factor that determines firm investment as both are perfect substitutes. Conversely, in an imperfect capital market (i.e. information asymmetry and agency costs), the cost of external capital will be higher than internally generated funds (Myers \& Majluf, 1984). In the same vein, Fazzari et al. (1988) argue that internal finance availability, access to financial markets, and financing cost may determine firms' investment. Furthermore, Faulkender and Petersen (2006) argue that the financing decision is determined by both supply and demand of capital. Cross-country studies by Rajan and Zingales (1995) and Booth et al. (2001) indicate that firms' capital structures are affected by financial market environment and the degree of financial development. More specifically, Schmukler and Vesperoni (2006) suggest that financial development is the main external condition that determines a firm's financing policy.

Financial development will reduce the cost of external funding and, therefore, provides a better debt financing alternative for the firm and encourages the firm to have a higher level of debt financing. In the case of an emerging economy - characterized by a less developed capital market - firms may rely more on internal capital markets and banks as sources of financing. The banking sector is still the main form of financial intermediation and is a major source of external capital. According to Fan et al. (2012) information asymmetry and contracting costs between firm and creditor are the crucial factors for firms' capital structure. In a well-developed financial system, banks can easily obtain debtors' information to avoid manager opportunistic behaviours, hence banks are willing to lend credit to firms with a low cost of debt (Diamond, 1991). In contrast, firms in a less developed financial system face a higher level of asymmetric information problems, so banks charge higher contracting costs to control their credit risk. Moreover, in less developed financial systems, banks prefer to provide long-term debt due to their capacity to collect information on debtors' economy of scale and supervise the debtors (Barclay \& Smith, 1995; Demirguc-Kunt \& Maksimovic, 1996) since they will face a higher level of asymmetric information and moral hazard problems with borrowers by providing short-term debt. Consequently, financial development provides an easy access for the firms to obtain external debt and lower the cost of debt (Guiso et al., 2004). Accordingly, as positive working capital requirement needs financing, one would predict that firms that operate in more financially developed regions will have higher optimal levels of short-term debt financing. Baños-Caballero et al. (2021) confirm that NWC adjustment speed is faster for firms that operate in countries with higher levels of financial development. Based on the above discussion, we propose the following hypothesis:

H2: The optimal proportion of short-term debt to finance working capital requirement is higher for firms in more financially developed regions.

\section{RESEARCH METHODOLOGY}

\section{Data}

The firm-level data used in this study were obtained from the Bloomberg database. The sample comprised publicly listed manufacturing firms of ASEAN-5 countries, namely Indonesia, Malaysia, Philippines, Singapore, and Thailand for the period of 2009-2018, resulting in 6183 firm-year observations. 
The selection of manufacturing firms was conducted according to Hill et al. (2010) in that manufacturing firms have different working capital policies from those of service firms. More specifically, manufacturing firms were characterized with high inventory levels, while the services sector could have no inventory at all. Therefore, to avoid bias due to differences in the business features among industrial sectors, this research employed manufacturing companies as samples.

\section{Empirical approach}

To estimate the effect of working capital financing on firm profitability, the analysis was based on equation (1) below, which followed Baños-Caballero et al. (2016). The study employed a quadratic function to capture the possible non-linear relationships and to identify the optimum point. Additional control variables were also included in the equation to control the possible bias that could arise on account of omitted variables.

$$
\begin{gathered}
R O A_{i, j, t}=\beta_{0}+\alpha R O A_{i, j, t-1}+\beta_{1} W C F_{i, j, t}+\beta_{2} W C F_{i, j, t}^{2}+\beta_{3} \text { Size }_{i, j, t}+ \\
+\beta_{4} \text { Growth }_{i, j, t}+\beta_{5} A T_{i, j, t}+\beta_{6} \operatorname{Lev}_{i, j, t}+\varphi_{t}+\delta_{i}+\varepsilon_{i, j, t}
\end{gathered}
$$

In the above equation, $i, j$, and $t$ represented firms, countries in which the firm locates, and time, respectively. The abbreviation ROA meant return on assets, which was measured by the ratio of net profit to total asset. The terms WCF and $\mathrm{WCF}^{2}$ were working capital financing which were measured by the ratio of short-term debt to working capital requirement. The inclusion of these two variables was meant to allow non-monotonic effects of working capital to firm profitability. If the inverted Ushape relationship between working capital financing and profitability was hypothesized, a positive sign on $\beta_{1}$ and a negative sign on $\beta_{2}$ were expected. Moreover, the break-even point beyond which the effect of working capital financing on firms' profitability would change was estimated by $-\beta_{1} / 2 \beta_{2}$. Following Baños-Caballero et al. (2016) and Altaf and Ahmad (2019), we controlled for firm size, sales growth, asset tangibility, and leverage. The detail operation definition of variables is presented in Table 1 below. In addition, the parameter $\varphi_{t}$ was a time dummy, $\delta_{i}$ was unobservable heterogeneity or time invariant individual fixed-effect component, and lastly, $\varepsilon_{i, j, t}$ was the residual error.

\begin{tabular}{|c|c|c|c|}
\hline Variables & Acronym & Definition & Sources \\
\hline \begin{tabular}{|l|} 
Dependent Variables \\
Return on assets
\end{tabular} & ROA & Net profit / total assets & Bloomberg \\
\hline $\begin{array}{l}\text { Independent variables } \\
\text { Working capital financing }\end{array}$ & WCF & $\begin{array}{l}\text { Short-term debt / working capital requirement } \\
\text { Where working capital requirement = current as- } \\
\text { sets - accounts payable }\end{array}$ & Bloomberg \\
\hline Working capital financing squared & WCF $^{2}$ & Square of WCF & Bloomberg \\
\hline $\begin{array}{l}\text { Moderation variables } \\
\text { Financial development }\end{array}$ & FD & Private sector credit to GDP & $\begin{array}{l}\text { https://data- } \\
\text { bank.worldbank.org }\end{array}$ \\
\hline & & Financial institution index & https://data.imf.org \\
\hline & & Financial development Index & https://data.imf.org \\
\hline Control variables & & & \\
\hline Firm size & Size & Natural logarithm of total assets & Bloomberg \\
\hline Growth & Growth & (Current year sales / previous year sales) - 1 & Bloomberg \\
\hline Asset tangibility & AT & Fixed assets / total assets & Bloomberg \\
\hline Leverage & Lev & Total debt / total assets & Bloomberg \\
\hline
\end{tabular}

Table 1. Variable's definition

Source: Baños-Caballero et al. (2016); Altaf and Ahmad (2019).

This study employed the panel data approach to estimate the model specifications. The approach was adopted because panel data methodology offers several benefits. Firstly, this method is developed to control for unobservable heterogeneity (Hsiao, 2014). Secondly, it provides more indicators, produces more variability, and less collinearity among variables (Hsiao, 2014). Lastly, it overcomes the 
endogeneity problem, as the error disturbances that affect dependent variables may also affect independent variables. Accordingly, the two-step generalized method of moments (GMM) approach developed by Arellano and Bond (1991) was employed to estimate the model specification; hence, endogeneity was controlled through the use of instrumental variables. Following Arellano and Bond (1991) the differenced lagged dependent variable and lagged differences of independent variables can be instrumented with their lags in levels, lagged two or more periods, while the exogenous variables can serve as their own instruments.

\section{RESULTS AND DISCUSSION}

\section{Descriptive and correlation analysis}

Table 2 below provides descriptive statistics of return on assets, working capital financing, and the control variables for all samples and specific countries in the form of mean, standard deviation, minimum, and maximum. In the sample, the average of ROA was 0.043 . This value was close to the average of member countries. The range of working capital financing was observed to range from zero to 0.991 , with an average of 0.468 , which implied that on average $46.8 \%$ of working capital requirement of ASEAN firms are financed through short-term debt. Moreover, standard deviation values also suggested the diversity of working capital financing strategy among sample firms. Interestingly, the examination of individual countries' data revealed that the average values are varied across countries. Indonesian firms on average had the highest percentage of short-term debt financing of working capital requirement, which indicated that Indonesian firms adopt more aggressive working capital financing strategy compared to other ASEAN counterparts. Singaporean firms have the lowest proportion of short-term debt financing of working capital. For the control variables, the average of firm size was 27.821 (in natural logarithm) and the average sales growth was around 0.122 . Furthermore, asset tangibility variable calculated by the ratio of fixed assets to total assets had the average value of 0.436 and mean value of leverage - total debt to total assets - was 0.181 , which suggested that ASEAN firms rely more on equity financing than debt financing.

Table 2. Descriptive statistics

\begin{tabular}{|c|c|c|c|c|c|c|}
\hline Country & Variables & $\mathbf{N}$ & Mean & SD & Min. & Max. \\
\hline \multirow{9}{*}{ ALL } & ROA & 6183 & 0.043 & 0.176 & -3.797 & 9.736 \\
\hline & WCF & 6183 & 0.468 & 0.655 & 0.000 & 0.991 \\
\hline & Size & 6183 & 27.821 & 1.536 & 23.082 & 33.323 \\
\hline & Growth & 6183 & 0.122 & 0.491 & -1.000 & 8.459 \\
\hline & AT & 6183 & 0.436 & 0.209 & 0.000 & 0.986 \\
\hline & Leverage & 6183 & 0.181 & 0.164 & 0.000 & 2.497 \\
\hline & Credit to GDP & 30 & 92.629 & 41.174 & 27.253 & 149.373 \\
\hline & FII & 30 & 0.394 & 0.056 & 0.297 & 0.450 \\
\hline & FDI & 30 & 0.553 & 0.164 & 0.294 & 0.760 \\
\hline \multirow{9}{*}{ IDN } & ROA & 751 & 0.055 & 0.364 & -0.755 & 9.736 \\
\hline & WCF & 751 & 0.456 & 0.635 & 0.000 & 0.823 \\
\hline & Size & 751 & 28.248 & 1.608 & 23.082 & 32.469 \\
\hline & Growth & 751 & 0.143 & 0.479 & -0.94 & 6.636 \\
\hline & AT & 751 & 0.489 & 0.215 & 0.039 & 0.952 \\
\hline & Leverage & 751 & 0.228 & 0.166 & 0.000 & 0.901 \\
\hline & Credit to GDP & 10 & 34.698 & 4.803 & 27.253 & 39.402 \\
\hline & FII & 10 & 0.394 & 0.056 & 0.297 & 0.450 \\
\hline & FDI & 10 & 0.345 & 0.026 & 0.294 & 0.380 \\
\hline \multirow{5}{*}{ MYS } & ROA & 2656 & 0.038 & 0.158 & -3.797 & 5.153 \\
\hline & WCF & 2656 & 0.407 & 0.517 & 0.000 & 0.991 \\
\hline & Size & 2656 & 27.531 & 1.445 & 23.803 & 32.833 \\
\hline & Growth & 2656 & 0.11 & 0.524 & -1.000 & 8.459 \\
\hline & AT & 2656 & 0.446 & 0.213 & 0.000 & 0.986 \\
\hline
\end{tabular}




\begin{tabular}{|c|c|c|c|c|c|c|}
\hline Country & Variables & $\mathbf{N}$ & Mean & SD & Min. & Max. \\
\hline & Leverage & 2656 & 0.169 & 0.141 & 0.000 & 0.989 \\
\hline & Credit to GDP & 10 & 116.445 & 5.775 & 107.122 & 123.104 \\
\hline & FII & 10 & 0.697 & 0.011 & 0.680 & 0.716 \\
\hline & $F D I$ & 10 & 0.662 & 0.017 & 0.629 & 0.690 \\
\hline \multirow{9}{*}{ PHL } & ROA & 156 & 0.064 & 0.060 & -0.278 & 0.344 \\
\hline & WCF & 156 & 0.461 & 0.410 & 0.000 & 0.883 \\
\hline & Size & 156 & 29.128 & 1.493 & 26.163 & 32.227 \\
\hline & Growth & 156 & 0.212 & 0.656 & -1.000 & 5.691 \\
\hline & AT & 156 & 0.522 & 0.203 & 0.009 & 0.980 \\
\hline & Leverage & 156 & 0.275 & 0.399 & 0.000 & 2.497 \\
\hline & Credit to GDP & 10 & 41.709 & 13.658 & 29.163 & 66.339 \\
\hline & FII & 10 & 0.367 & 0.035 & 0.314 & 0.440 \\
\hline & $F D I$ & 10 & 0.369 & 0.019 & 0.335 & 0.392 \\
\hline \multirow{9}{*}{ SGP } & ROA & 1499 & 0.035 & 0.115 & -1.077 & 1.762 \\
\hline & WCF & 1499 & 0.367 & 0.553 & 0.000 & 0.878 \\
\hline & Size & 1499 & 27.936 & 1.441 & 23.896 & 33.323 \\
\hline & Growth & 1499 & 0.122 & 0.485 & -1.000 & 7.677 \\
\hline & AT & 1499 & 0.362 & 0.192 & 0.003 & 0.954 \\
\hline & Leverage & 1499 & 0.168 & 0.147 & 0.000 & 1.049 \\
\hline & Credit to GDP & 10 & 115.273 & 12.219 & 94.858 & 128.130 \\
\hline & FII & 10 & 0.719 & 0.030 & 0.673 & 0.770 \\
\hline & $F D I$ & 10 & 0.718 & 0.019 & 0.697 & 0.760 \\
\hline \multirow{9}{*}{ THA } & ROA & 1121 & 0.054 & 0.076 & -0.517 & 0.624 \\
\hline & WCF & 1121 & 0.530 & 0.625 & 0.000 & 0.960 \\
\hline & Size & 1121 & 27.89 & 1.636 & 24.785 & 33.204 \\
\hline & Growth & 1121 & 0.125 & 0.385 & -0.891 & 4.659 \\
\hline & AT & 1121 & 0.125 & 0.192 & 0.011 & 0.971 \\
\hline & Leverage & 1121 & 0.184 & 0.169 & 0.000 & 0.786 \\
\hline & Credit to GDP & 10 & 136.509 & 13.917 & 108.983 & 149.373 \\
\hline & FII & 10 & 0.691 & 0.056 & 0.590 & 0.750 \\
\hline & $F D I$ & 10 & 0.674 & 0.046 & 0.583 & 0.730 \\
\hline
\end{tabular}

Notes: SD - standard deviation; Min. - minimum; Max. - maximum; ALL - all samples; IDN - Indonesia; MYS - Malaysia; PHL - Philippines; SGP - Singapore; THA - Thailand.

Source: own elaboration in Stata.

Table 3 below presents the coefficients of pairwise correlation for all samples, but also for individual countries' data. The ROA was negatively correlated with WCF, while the results were similar for all sub samples. Size and growth had positive correlation with firm profitability, while asset tangibility and leverage showed negative correlation with ROA. Moreover, to ensure that the analysis was free from the multicollinearity problem, this study estimated variance inflation factor (VIF) to independent variables in all model estimations. The results indicated that none of the VIF values was higher than 5 , which implied that the analysis was free from the multicollinearity problem.

Table 3. Correlation matrix

\begin{tabular}{|l|c|c|c|c|c|c|}
\hline \multicolumn{1}{|c|}{ Variables } & ROA & WCF & Size & Growth & AT & Leverage \\
\hline ROA & 1 & & & & & \\
\hline WCF & $-0.0756^{* * *}$ & 1 & & & & \\
\hline Size & $0.0505^{* *}$ & $0.0948^{*}$ & 1 & & & \\
\hline Growth & $0.0573^{* *}$ & -0.0184 & $0.0331^{*}$ & 1 & & \\
\hline AT & $-0.0250^{*}$ & $0.1493^{* *}$ & $0.1839^{* * *}$ & $-0.0294^{*}$ & 1 & \\
\hline Leverage & $-0.0653^{* *}$ & $0.4709^{*} *$ & $0.3015^{*}$ & 0.0251 & $0.1401^{* *}$ & 1 \\
\hline
\end{tabular}

Notes: $* * *, * *, *$ denote statistical significances at $1 \%, 5 \%$, and $10 \%$ levels, respectively.

Source: own elaboration in Stata. 


\section{Working capital financing and firm profitability}

Table 4 below presents the two-step GMM estimation results of the effect of working capital financing on firm profitability, which was estimated based on equation (1). The Table reports the estimation results for all samples and subsamples of individual countries. The serial correlation $A R(2)$ test - indicated by the $p$-values of $m_{2}$ - confirmed that there is no second order serial correlation in all model estimations. In addition, the Sargan test to estimates the presence of correlation between instrument variables and error term showed non-significant results indicated by the $p$-values, which implied that there is no correlation between instrument variables and error term.

Table 4. Working capital financing and firm profitability

\begin{tabular}{|l|c|c|c|c|c|c|}
\hline \multicolumn{1}{|c|}{ Variables } & ALL & IDN & MYS & PHL & SGP & THA \\
\hline ROA $_{\mathrm{t}-1}$ & $-0.079^{* *}$ & $-0.047^{* *}$ & $-0.300^{* *}$ & $-0.554^{* * *}$ & $-0.095^{* * *}$ & $-0.222^{* * *}$ \\
& $(0.034)$ & $(0.020)$ & $(0.025)$ & $(0.139)$ & $(0.036)$ & $(0.082)$ \\
\hline WCF & $0.529^{* * *}$ & $0.058^{* * *}$ & $0.817^{* * *}$ & $0.054^{* * *}$ & $0.283^{* * *}$ & $-0.137^{* *}$ \\
& $(0.148)$ & $(0.020)$ & $(0.231)$ & $(0.014)$ & $(0.078)$ & $(0.056)$ \\
\hline WCF $^{2}$ & $-0.342^{* * *}$ & $-0.031^{* *}$ & $-0.528^{* * *}$ & $-0.037^{* * *}$ & $-0.193^{* * *}$ & $0.115^{* *}$ \\
& $(0.097)$ & $(0.013)$ & $(0.157)$ & $(0.010)$ & $(0.054)$ & $(0.054)$ \\
\hline Size & $0.044^{* * *}$ & $0.008^{* * *}$ & $0.090^{* * *}$ & $-0.003^{* * *}$ & $0.006^{* *}$ & $0.002^{* *}$ \\
& $(0.007)$ & $(0.002)$ & $(0.006)$ & $(0.001)$ & $(0.002)$ & $(0.001)$ \\
\hline Growth & $0.116^{* *}$ & $0.058^{* *}$ & $0.086^{* *}$ & 0.002 & $0.186^{* * *}$ & $0.036^{* * *}$ \\
& $(0.047)$ & $(0.023)$ & $(0.037)$ & $(0.012)$ & $(0.027)$ & $(0.007)$ \\
\hline AT & $-2.583^{* * *}$ & $-0.208^{* *}$ & $-5.982^{* * *}$ & $0.155^{* *}$ & $-0.687^{* * *}$ & -0.020 \\
& $(0.562)$ & $(0.101)$ & $(0.329)$ & $(0.065)$ & $(0.190)$ & $(0.013)$ \\
\hline Lev & $-2.435^{* *}$ & $-0.646^{* * *}$ & $-2.635^{*}$ & 0.0164 & $-0.811^{* *}$ & $-0.074^{* * *}$ \\
& $(1,165)$ & $(0.103)$ & $(1,358)$ & $(0.015)$ & $(0.396)$ & $(0.018)$ \\
\hline Industry fixed effect & Yes & Yes & Yes & Yes & Yes & Yes \\
\hline Country Fixed effect & Yes & No & No & No & No & No \\
\hline m (P-value) & 0.334 & 0.870 & 0.112 & 0.162 & 0.959 & 0.312 \\
\hline Sargan (P-value) & 0.676 & 0.127 & 0.151 & 0.777 & 0.434 & 0.292 \\
\hline N (observations) & 6183 & 751 & 2656 & 156 & 1499 & 1121 \\
\hline
\end{tabular}

Notes: Table 4 was estimated based on equation (1). Number in parentheses are standard errors. ***, **, * denote statistical significances at $1 \%, 5 \%$, and $10 \%$ levels, respectively. ALL - all samples; IDN - Indonesia; MYS - Malaysia; PHL - Philippines; SGP - Singapore; THA: -Thailand. Instrument used was first lag of WCF. $\mathrm{m} 2$ was serial correlation test with the null of no second order autocorrelation.

Source: own elaboration in Stata.

Furthermore, as inferred from all sample results, there appeared a positive and significant coefficient of WCF, while the coefficient $\beta_{2}$ of $\mathrm{WCF}^{2}$ was negative and significant at the level of $1 \%$. The results supported the first hypothesis that the effect of working capital financing and firm profitability was non-monotonic, following an inverted U-shape. In addition, the results were consistent for individual country subsamples, namely Indonesia, Malaysia, Singapore, and Philippines.

These results suggested that in a low level of short-term debt financing of working capital, additional short-term debt financing will increase firm profitability because the firm will receive benefits associated with short-term debt. Specifically, rather than long-term debt, lower interest rates have a better credit condition as a result of a good firm-bank relationship, they reduce agency problems between shareholders and debtholders, reduce the cost of equity agents, and minimize the risk of underinvestment (Ozkan, 2000; Baños-Caballero et al., 2016). Conversely, for firms with a high percentage of working capital requirement financed by short-term debt, additional short-term debt financing will have negative effects on firm profitability. As the proportion of short-term debt exceeds the optimal level, the risk of short-term debt financing outweighs the benefits. According to Jun and Jen (2003), firms will face higher refinancing and interest rate risk if the working capital requirement of financing uses a large proportion of short-term debt, which in turn will cause financial distress costs. Moreover, 
the optimum point beyond which firm profitability tends to decrease was estimated. The results suggested that the approximate breakpoint for all sample was 0.773 , estimated based on $\left(-\beta_{1} / 2 \beta_{2}\right)$.

Contrary to the main results, there appeared interesting results for the case of Thailand: the coefficient of $\beta_{1}$ was negative and significant, while the coefficient of $\beta_{2}$ was positive and significant. This implied that aggressive working capital financing strategy is more profitable than a conservative strategy thanks to Thailand's financial development level, which is the highest among all the ASEAN countries (see the mean value of credit to GDP ratio in Table 2), hence it is easier for Thai firms to obtain financing from financial institutions with low cost.

Table 5. Working capital financing and firm profitability (spline regression)

\begin{tabular}{|l|c|c|c|c|c|c|}
\hline \multicolumn{1}{|c|}{ Variables } & ALL & IDN & MYS & PHL & SGP & THA \\
\hline ROAt-1 & $-0.065^{* *}$ & $0.071^{* *}$ & $-0.297^{* *}$ & $-0.572^{* * *}$ & $-0.087^{* *}$ & $-0.075^{* *}$ \\
& $(0.032)$ & $(0.031)$ & $(0.028)$ & $(0.141)$ & $(0.037)$ & $(0.032)$ \\
\hline WCF & $0.287^{* * *}$ & $0.029^{* * *}$ & $0.488^{* * *}$ & $0.011^{* *}$ & $0.168^{* * *}$ & $-0.009^{* *}$ \\
& $(0.086)$ & $(0.011)$ & $(0.131)$ & $(0.004)$ & $(0.045)$ & $(0.004)$ \\
\hline (WCF-WCF*)Z & $-0.472^{* * *}$ & $-0.040^{*}$ & $-0.846^{* * *}$ & $-0.026^{* * *}$ & $-0.233^{* * *}$ & $0.017^{*}$ \\
& $(0.144)$ & $(0.021)$ & $(0.229)$ & $(0.007)$ & $(0.063)$ & $(0.009)$ \\
\hline Size & $0.044^{* * *}$ & $0.009^{* * *}$ & $0.093^{* * *}$ & $-0.003^{* * *}$ & $0.006^{* *}$ & $0.003^{* * *}$ \\
& $(0.007)$ & $(0.002)$ & $(0.007)$ & $(0.001)$ & $(0.002)$ & $(0.000)$ \\
\hline Growth & $0.129 * * *$ & $0.059^{* *}$ & $0.083^{* *}$ & 0.002 & $0.191^{* * *}$ & $0.031^{* * *}$ \\
& $(0.047)$ & $(0.023)$ & $(0.038)$ & $(0.013)$ & $(0.025)$ & $(0.007)$ \\
\hline AT & $-2.413^{* * *}$ & $-0.207^{*}$ & $-6.102^{* * *}$ & $0.158^{* *}$ & $-0.661^{* * *}$ & -0.020 \\
& $(0.557)$ & $(0.106)$ & $(0.345)$ & $(0.069)$ & $(0.188)$ & $(0.015)$ \\
\hline Leverage & $-2.394^{* * *}$ & $-0.646^{* * *}$ & $-2.507^{*}$ & 0.016 & $-0.734^{* *}$ & $-0.086^{* * *}$ \\
& $(1.103)$ & $(0.106)$ & $(1.363)$ & $(0.016)$ & $(0.350)$ & $(0.021)$ \\
\hline Industry fixed effect & Yes & Yes & Yes & Yes & Yes & Yes \\
\hline Country Fixed effect & Yes & No & No & No & No & No \\
\hline m2 (P-value) & 0.111 & 0.900 & 0.114 & 0.173 & 0.956 & 0.289 \\
\hline Sargan (P-value) & 0.666 & 0.142 & 0.176 & 0.794 & 0.112 & 0.158 \\
\hline N (observations) & 6183 & 751 & 2656 & 156 & 1499 & 1121 \\
\hline
\end{tabular}

Notes: Table 5 was estimated based on equation (2). Number in parentheses are standard errors. ***, **, * denote statistical significances at $1 \%, 5 \%$, and $10 \%$ levels, respectively. ALL - all samples; IDN - Indonesia; MYS - Malaysia; PHL - Philippines; SGP - Singapore; THA - Thailand. Instrument used was first lag of WCF. m2 was serial correlation test with the null of no second order autocorrelation.

Source: own elaboration in Stata.

We performed further analysis to ascertain the robustness of the previous results. Following Pattillo et al. (2002) and Altaf and Ahmad (2019), we applied the alternative estimation approach: spline regression. For that purpose, the equation (1) was transformed as follows:

$$
\begin{aligned}
& R O A_{i, j, t}=\beta_{0}+\alpha R O A_{i, j, t-1}+\beta_{1} W C F_{i, j, t}+\beta_{2}\left(W C F_{i, j, t}-W C F_{i, j, t}^{*}\right) Z+ \\
& +\beta_{3} \text { Size }_{i, j, t}+\beta_{4} \text { Growth }_{i, j, t}+\beta_{5} A T_{i, j, t}+\beta_{6} \operatorname{Lev}_{i, j, t}+\varphi_{t}+\delta_{i}+\varepsilon_{i, j, t}
\end{aligned}
$$

In the above equation, WCF* was the breakeven point calculated based on results of equation (1). The variable $Z$ was a dummy variable that equals one (1) if the corresponding $\left(W C F_{i, t}-W C F_{i, t}^{*}\right)$ value is positive and zero (0) if otherwise. More specifically, if the inverted U-shape effect of working capital financing on firm profitability was proved, then we expected $\beta_{1}$ to be positive and $\beta_{2}$ to be negative in equation (2).

Table 5 provides the results of spline regression. The results bear close resemblance with the results reported in Table 4, namely the expected results of positive and significant value of $\beta_{1}$ became apparent. Furthermore, we confirmed that $\beta_{2}$ as the coefficient of $\left(W C F_{i, t}-W C F_{i, t}^{*}\right) Z$ was negative and significant at 1 percent level of significance. These results reaffirmed the previous results that the effect of working capital financing on profitability is non-monotonic. 


\section{The influence of financial development on the effect of working capital financing on firm profitability}

Previous studies in working capital financing issues (i.e., Baños-Caballero et al., 2016; Altaf \& Ahmad, 2019; Pandan \& Nanda, 2018) empirically examined the role of financial constraints in determining working capital financing and profitability relationships. However, no study has yet investigated the external factors that may affect the working capital financing and profitability relationship. As argue Booth et al. (2001), firms' financing decisions are affected by the financial market environment and the level of financial development. More specifically, Schmukler and Vesperoni (2006) suggest that financial development is the main external factor that determines firms' financing policy. Financial development will provide an easy access for the firms to obtain external debt with lower cost of financing (Guiso et al., 2004). Accordingly, firms which operate in more financially developed regions will have higher optimal levels of short-term debt financing. Therefore, we proposed as the main contribution of this study the financial development variable and transformed equation (1) as follows:

$$
\begin{gathered}
R O A_{i, j, t}=\beta_{0}+\alpha R O A_{i, j, t-1}+\left(\beta_{1}+\gamma_{1} F D_{j, t}\right) W C F_{i, j, t}+\left(\beta_{2}+\gamma_{2} F D_{j, t}\right) W C F_{i, j, t}^{2}+ \\
+\beta_{3} \text { Size }_{i, j, t}+\beta_{4} \text { Growth }_{i, j, t}+\beta_{5} A T_{i, j, t}+\beta_{6} \operatorname{Lev}_{i, j, t}+\varphi_{t}+\delta_{i}+\varepsilon_{i, j, t}
\end{gathered}
$$

In the above equation, FD denoted the financial development scores of the country member. Country financial development was measured by the ratio of private credit to GDP; this ratio is a commonly used proxy in previous literature to measure financial development (e.g. Rajan \& Zingales, 1998; Cull et al., 2011; Lei et al., 2018). In addition, to have a more robust analysis, we employed alternative measures of financial development, namely financial institution index and financial development index. These indices are developed and published in International Monetary Fund statistics.

We expected that the optimal point of inverted U-shape relationship between working capital financing and firm profitability will be higher for firms that operate in more financially developed regions. The proposition was to be confirmed if the estimated value of the interaction terms in equation (4), i.e., $-\left(\beta_{1}+\gamma_{1}\right) / 2\left(\beta_{2}+\gamma_{2}\right)$ wa higher than the estimated value of $\left(-\beta_{1} / 2 \beta_{2}\right)$.

The estimation results of equation (3) are presented in Table 6 . As we can see, the coefficient of WCF was positive and significant, while the coefficient of $\mathrm{WCF}^{2}$ emerged as negative and significant, which implied the inverted $\mathrm{U}$-shape effect of working capital financing on firm profitability. Moreover, the estimated value of $-\left(\beta_{1}+\gamma_{1}\right) / 2\left(\beta_{2}+\gamma_{2}\right)$ was 0.872 for domestic credit to GDP criteria, 0.819 for financial institution index criteria, and 0.792 for financial development index criteria, which were higher than estimated optimal value in equation 1 (Table 4), with $p$-value of comparison being $(0.000),(0.005)$, and $(0.145)$, respectively. This implied that the break-even point is higher for companies that operate in more financially developed regions. This may be so because financial development will provide a flexible access for individual and firms to financial institutions as financing sources. Thus, increasing the accessibility of alternative credit sources fosters firm investment and growth. Financial development will reduce transaction costs of saving and hence lower cost of debt. Moreover, the development of financial institutions will help firms to reduce moral hazards and adverse selection problems, hence reducing the differential cost of external finance (Rajan \& Zingales, 1998). 
Table 6. Financial Development and working capital financing-firm profitability relationship

\begin{tabular}{|c|c|c|c|}
\hline Variables & Domestic credit to GDP & Financial institution index & Financial development index \\
\hline \multirow[t]{2}{*}{$\mathrm{ROA}_{\mathrm{t}-1}$} & $-0.199 * * *$ & $-0.474 * * *$ & $-0.073 * * *$ \\
\hline & $(0.009)$ & $(0.013)$ & $(0.020)$ \\
\hline \multirow[t]{2}{*}{ WCF } & $0.613^{* * *}$ & $0.635^{* *}$ & $0.594^{* * *}$ \\
\hline & $(0.087)$ & $(0.302)$ & $(0.198)$ \\
\hline \multirow[t]{2}{*}{ WCF $\times$ FD } & $-0.217^{* *}$ & $-0.253^{* * *}$ & $-0.320 * * *$ \\
\hline & $(0.094)$ & $(0.066)$ & $(0.098)$ \\
\hline \multirow[t]{2}{*}{ WCF $^{2}$} & $-0.230 * *$ & $-0.242^{* *}$ & $-0.210 * * *$ \\
\hline & $(0.110)$ & $(0.104)$ & $(0.077)$ \\
\hline \multirow[t]{2}{*}{$\mathrm{WCF}^{2} \times \mathrm{FD}$} & $0.002^{* * *}$ & $0.009 * * *$ & $0.037 * * *$ \\
\hline & $(0.000)$ & $(0.003)$ & $(0.013)$ \\
\hline \multirow[t]{2}{*}{ Size } & $0.004 * *$ & $0.004 * * *$ & $-0.014 * * *$ \\
\hline & $(0.001)$ & $(0.000)$ & $(0.005)$ \\
\hline \multirow[t]{2}{*}{ Growth } & $0.039 * * *$ & $0.013 * *$ & $0.019 *$ \\
\hline & $(0.011)$ & $(0.006)$ & $(0,010)$ \\
\hline \multirow[t]{2}{*}{ AT } & $-1.265 * * *$ & $-0.032 * *$ & $0.967 * * *$ \\
\hline & $(0.483)$ & $(0.014)$ & $(0.338)$ \\
\hline \multirow[t]{2}{*}{ Leverage } & $-1.309 * * *$ & $-0.087 * * *$ & $0.587 * *$ \\
\hline & $(0.188)$ & $(0.018)$ & $(0.202)$ \\
\hline Industry fixed effect & Yes & Yes & Yes \\
\hline Country Fixed effect & Yes & No & No \\
\hline$m_{2}$ (p-value) & 0.193 & 0.180 & 0.290 \\
\hline Sargan ( $p$-value) & 0.232 & 0.314 & 0.377 \\
\hline N (observations) & 6183 & 6183 & 6183 \\
\hline
\end{tabular}

Notes: Table 6 was estimated based on equation (3). Number in parentheses are standard errors. $* * *, * *, *$ denote statistical significances at $1 \%, 5 \%$, and $10 \%$ levels, respectively. Instrument used was first lag of WCF. m2 was serial correlation test with the null of no second order autocorrelation.

Source: own elaboration in Stata.

\section{CONCLUSIONS}

The empirical relations between working capital financing and firm profitability were previously scrutinized by few empirical studies. This article contributes to the matter by examining the mediating role of financial development on the effect of working capital financing on firm profitability of the ASEAN manufacturing firms. The focus on the ASEAN was motivated by the present concern on ASEAN's economic and financial development that offers unique features. The regional setting may impose a significant effect on working capital financing strategy applied by companies and outcomes that result from financing policies. The analysis was conducted in a panel data setting, and the generalized method of moment (GMM) approach of estimation was applied in order to control for possible heterogeneity and endogeneity problems.

The results reveal the inverted U-shape relation between working capital financing and firm profitability, suggesting that the effect of working capital financing on firm performance is non-monotonic. In firms with a low-level ratio of short-term debt to working capital requirement, an additional shortterm debt increases firm performance; conversely, in firms with a high proportion of short-term debt relative to working capital requirement, additional working capital decreases firm performance. It implies the existence of an optimum level of financing in working capital requirement that balances benefits and costs resulting from short-term debt. These results strengthen the previous finding of the inverted U-shape relationship between working capital financing and firm profitability.

The main contribution of our study is the examination of the role played by financial development in determining the effect of working capital financing on firm performance. While firms' financial constraints are internal factors, countries' financial development is an external factor that determines firms' ability to access external financing. As argued by Rajan and Zingales (1998) and Guiso et al. (2004), financial development will provide firms with easy access to external debt and 
lower debt costs. More specifically, our findings show that even though the inverted U-shape relationship between working capital financing and profitability holds, the optimum level of working capital financing is higher in countries with more developed financial systems. Financial development expands firms' financing sources, reduces financial constraints, and effectively decreases costs of external financing. The results are robust to the introduction of various proxies of country levels of financial development.

We identified potentially important implications for working capital management. Firstly, given the evidence of the inverted U-shape relationship between working capital financing and profitability, corporate managers should put greater emphasis on maximizing its utility for the benefit of firm performance. More specifically, corporate managers should avoid using too much short-term debt to finance their working capital requirement as the risk of refinancing and interest outweighs its benefit. Secondly, given the significant role played by financial development in determining working capital financing and firm performance relationship, policymakers should give priority to financial reforms and development to ensure firms with access to finance, hence foster their growth for the benefit of the economy.

The limitation of this study is related to the employed sample - the ASEAN region - which is typical of emerging markets, meaning that these findings are partly generalizable to markets with similar characteristics. Therefore, further research is needed to better understand how the relationship between working capital funding and firm performance differs across countries with different institutional and financial systems.

\section{REFERENCES}

Aktas, N., Croci, E., \& Petmezas, D. (2015). Is working capital management value-enhancing? Evidence from firm performance and investments. Journal of Corporate Finance, 30(2015), 98-113. https://doi.org/10.1016/j.jcorpfin.2014.12.008

Almeida, H., Campello, M., \& Weisbach, M.S. (2004). The cash flow sensitivity of cash. Journal of Finance, 59(4), 1777-1804. https://doi.org/10.1111/j.1540-6261.2004.00679.x

Altaf, N., \& Ahmad, F. (2019). Working capital financing, firm performance and financial constraints: Empirical evidence from India. International Journal of Managerial Finance, 15(4), 464-477. https://doi.org/10.1108/APJBA-06-2017-0057

Arellano, M., \& Bond, S. (1991). Some test of specification for panel data: Monte Carlo evidence and an application to employment equations. Review of Economics Studies, 58(2), 277-297. https://doi.org/10.2307/2297968

Barclay, M., \& Smith, W. (1995). The maturity structure of corporate debt. Journal of Finance, 50(2), 609-631. https://doi.org/10.1111/j.1540-6261.1995.tb04797.x

Baños-Caballero, S., García-Teruel, P.J., \& Martínez-Solano, P. (2014). Working capital management, corporate performance, and financial constraints. Journal of Business Research, 67(3), 332-338. https://doi.org/10.1016/j.jbusres.2013.01.016

Baños-Caballero, S., García-Teruel, P.J., \& Martínez-Solano, P. (2016). Financing of working capital requirement, financial flexibility and SME performance. Journal of Business Economics and Management, 17(6), 11891204. https://doi.org/10.3846/16111699.2015.1081272

Baños-Caballero, S., García-Teruel, P.J., \& Martínez-Solano, P. (2021). The speed of adjustment in net operating working capital: an international study. Spanish Journal of Finance and Accounting, 50, https://doi.org/10.1080/02102412.2020.1864176

Booth, L., Aivazian, V., Demirguc-Kunt, A., \& Maksimovic, V. (2001). Capital structures in developing countries. Journal of Finance, 56(1), 87-130. https://doi.org/10.1111/0022-1082.00320

Carpenter, R. E., Fazzari, S. M., \& Petersen, B. C. (1994). Inventory investment, internal finance fluctuations, and the business cycle. Brookings Papers on Economic Activity, 2, 75-138. https://doi.org/10.2307/2534655

Charitou, M., Lois, P., \& Santoso, H. B. (2012). The relationship between working capital management and firm's profitability: An empirical investigation for an emerging Asian country. International Business and Economics Research Journal, 11(8), 839 - 848. https://doi.org/10.19030/iber.v11i8.7162

Cull, R., Haber, S., \& Imai, M. (2011). Related lending and banking development. Journal of International Business Studies, 42(3), 406-426. https://doi.org/10.1596/1813-9450-5570

De Carvalho, A.G.D. (2009). The effect of institutions on the external financing of Brazilian firms. Revista Brasileira de Finanas, 7(1), 1-27. https://www.redalyc.org/pdf/3058/305824747001.pdf 
Deloof, M. (2003). Does working capital management affect profitability of Belgian firms? Journal Business Finance and Accounting, 30(3-4), 573-587. https://doi.org/10.1111/1468-5957.00008

Demirguc-Kunt, A., \& Maksimovic, V. (1996). Stock market development and firm financing choices. World Bank Economic Review, 10(2), 341-369. https://doi.org/10.1093/wber/10.2.341

Diamond, D. (1991). Debt maturity structure and liquidity risk. Quarterly Journal of Economics, 106(3), 709-737. https://doi.org/10.2307/2937924

Fan, J.P.H., Titman, S., \& Twite, G. (2012). An international comparison of capital structure and debt maturity choices. Journal of Financial and Quantitative Analysis, 47(1), 23-56. doi:10.1017/s0022109011000597

Faulkender, M., \& Petersen, M.A. (2006). Does the source of capital affect capital structure?. Review of Financial Studies, 19(1), 45-79. https://doi.org/10.1093/rfs/hhj003

Faulkender, M., \& Wang, R. (2006). Corporate financial policy and the value of cash. Journal of Finance, 61(4), 1957-1990. https://doi.org/10.1111/j.1540-6261.2006.00894.x

Fazzari, S.M., Hubbard, R.G., \& Petersen, B.C. (1988). Financing constraints and corporate investment. Brookings Papers on Economic Activity, 1, 141-2016. DOI 10.3386/w2387

Fazzari, S.M., \& Petersen, B. (1993). Working capital and fixed investment: new evidence on financing constraints. The RAND Journal of Economics, 24(3), 328-342. https://doi.org/10.2307/2555961

Gertner, R.H., Scharfstein, D.S., \& Stein, J.C. (1994). Internal versus external capital markets. The quarterly journal of economics, 109(4), 1211-1230. https://doi.org/10.2307/2118361

Guiso, L., Sapienza, P., \& Zingales, L. (2004). Does local financial development matter? Quarterly Journal of Economics, 119(3), 929-969. https://doi.org/10.1162/0033553041502162

Hill, M., Kelly, G., \& Highfield. J. (2010). Net operating working capital behaviour: A first look. Financial Management, 39(2), 783-805. https://doi.org/10.1111/j.1755-053X.2010.01092.x

Hsiao, C. (2014). Analysis of panel data, 3rd ed. Cambridge University Press, Cambridge, United Kingdom.

Jun, S.G., \& Jen, F.C. (2003). Trade-off model of debt maturity structure. Review of Quantitative Finance and Accounting, 20(1), 5-34. https://doi.org/10.1023/A:1022190205033

Kieschnick, R., Laplante, M., \& Moussawi, R. (2013). Working capital management and shareholders' wealth. Review of Finance, 17(5), 1827-1852. https://doi.org/10.1093/rof/rfs043

Lee, C., Shie, F.S., \& Chang, C.Y. (2012). How close a relationship does a capital market have with other such market? The case of Taiwan from the Asian financial crisis. Pacific-Basin Finance Journal, 20(3), 349-362. https://doi.org/10.1016/j.pacfin.2011.11.003

Lei, J., Qiu, J., \& Wan, C. (2018). Asset tangibility, cash holding, and financial development. Journal of Corporate Finance, 50(2018), 223-242. https://doi.org/10.1016/j.jcorpfin.2018.03.008

Mishkin, F.S. (2001). The transmission mechanism and the role of asset prices in monetary policy. NBER working paper, No. 8617, Massachusetts Avenue, Cambridge, USA. DOI 10.3386/w8617

Modigliani, F., \& Miller, M. H. (1958). The cost of capital, corporation finance and the theory of investment: reply. American Economic Review, 48(4), 261-297. http://www.jstor.org/stable/1812919

Myers, S., \& Majluf, N. (1984). Corporate financing and investment decisions when firms have information that investors do not have. Journal of Financial Economics, 13(2), 187-221. https://doi.org/10.1016/0304-405X(84)90023-0

Ozkan, A. (2000). An empirical analysis of corporate debt maturity structure. European Financial Management, 6(2), 197-212. https://doi.org/10.1111/1468-036X.00120

Panda, A.J., \& Nanda, K. (2018). Working capital financing and corporate profitability of Indian manufacturing firms. Management Decision, 56(2), 441-457. https://doi.org/10.1108/MD-07-2017-0698

Pattillo, C., Poirson, H., \& Ricci, L. (2002). External Debt and Growth. IMF Working Paper, International Monetary Fund, Washington, April 2002. https://ssrn.com/abstract $=879569$

Rajan, R.G., \& Zingales, L. (1995). What do we know about capital structure? Some evidence from international data. Journal of Finance, 50(5), 1421-1460. https://doi.org/10.1111/j.1540-6261.1995.tb05184.x

Rajan, R.G., \& Zingales, L. (1998). Financial dependence and growth. American Economic Review, 88(3), 559-586. DOI 10.3386/w5758

Setianto, R.H., \& Kusumaputra, A. (2017). Corporate financial flexibility, investment activities, and cash holding: evidence from Indonesia. Indonesian Capital Market Review, 15(1), 39-50. https://doi/org/10.21002/icmr.v9i2.7470 
Setianto, R.H., \& Pratiwi, A. (2019). Working capital management in Indonesia: an analysis on overinvestment and underinvestment firms. Gadjah Mada International Journal of Business, 21(1), 1-18. DOI: 10.22146/gamaijb.28354

Smith, K. (1980). Profitability versus liquidity trade-offs in working capital management, Smith, K.V. (Ed.), Readings on the management of working capital. West Publishing Company, St Paul, M, 549-562.

Schmukler, S., \& Vesperoni, E. (2006). Financial globalization and debt maturity in emerging economies. Journal of Development Economics, 79(1), 183-207. https://doi.org/10.1016/j.jdeveco.2004.12.006

Van Horne, J.C. (1969). A risk and return analysis of a firm's working capital position. Engineering Economist, $14(2), 71-89$.

\section{Authors}

The contribution share of authors are as follows: Rahmat Heru Setianto (50\%) - conceptualization, writing original draft, formal analysis, investigation, methodology. Rani Septiani Sipayung (30\%) - data collection and analysis, conclusion. W.N.W. Azman-Saini (20\%) - review, editing, supervision, validation, visualization.

\section{Rahmat Heru Setianto}

PhD Candidate at the School of Business and Economics, Universiti Putra Malaysia, Selangor Malaysia, and Lecturer at The Faculty of Economics and Business, Universitas Airlangga, Surabaya Indonesia.

Correspondence to: Rahmat Heru Setianto, Faculty of Economics and Business, Universitas Airlangga, JL. Airlangga 4, Surabaya, Indonesia, 60286, e-mail: rahmat.heru@feb.unair.ac.id ORCID (1) http://orcid.org/0000-0001-6007-2733

\section{Rani Septiani Sipayung}

Business Consultant at AKRUA Consulting, Jakarta, Indonesia. Her research interests include corporate finance, capital market, banking.

Correspondence to: Rani Septiani Sipayung, AKRUA Consulting, JL. Kemang Raya No. 30, Mampang Prapatn, Jakarta, Indonesia 12730, e-mail: ranisipayung99@gmail.com

ORCID (1) http://orcid.org/0000-0003-3550-2679

\section{W.N.W. Azman-Saini}

Associate Professor at the School of Business and Economics, Universiti Putra Malaysia, Selangor, Malaysia. His research interest include financial economics and international economics.

Correspondence to: W.N.W Azman-Saini, School of Business Economics, Universiti Putra Malaysia 43400 Serdang, Selangor, Malaysia, e-mail: wazman@upm.edu.my

ORCID (1) https://orcid.org/0000-0002-3108-6789

\section{Acknowledgements and Financial Disclosure}

The authors would like to thank the anonymous referees for their useful comments, which allowed to increase the value of this article.

\section{Conflict of Interest}

The authors declare that the research was conducted in the absence of any commercial or financial relationships that could be construed as a potential conflict of interest.

\section{Copyright and License}

This article is published under the terms of the Creative Commons

Attribution - NoDerivs (CC BY-ND 4.0) License

http://creativecommons.org/licenses/by-nd/4.0/ 